Environment Conservation Journal 15(1 \&2)49-54, 2014

ISSN 0972-3099 (Print) 2278-5124 (Online)

Abstracted and Indexed

\title{
Dynamics of synchronized clinostomatids infections in Cichlids
}

\author{
Echi, P. C ${ }^{1}$, Iyaji, F. O $^{2}$, Ejere, V. $C^{2}$ and Abuh, S. J ${ }^{2}$ \\ Received: 09.09.2013 \\ Revised: 21.12.2013
}

Accepted: 16.01.2014

\begin{abstract}
Histopathology of fish in a concomitant infection of three different species of clinostomatid metacercariae: Clinostomum tilapiae, Clinostomum complanatum, and Euclinostomum heterostomum has become necessary due to its want of knowledge. Description of enormous debilitating skin damages, occasional deaths, unilateral exophthalmus, and degeneration of skin, myositis, haemorrhages, eosinophils, necrosis and economic destruction of Tilapia zillii values by these metacercariae were studied. These parasites dry body weights $(\mathrm{mg}) ; C$. complanatum $\left(0.0071 \pm 0.0023^{\mathrm{b}}\right)$ and $E$. heterostomum $(0.0067 \pm 0.0023$ b $)$ did not show any significant difference $(P<0.05 \%)$, whereas $C$. complanatum and $E$. heterostomum showed significant difference with $C$. tilapiae $\left(0.0050 \pm 0.0015^{\mathrm{a}}\right)$. The effects of hydrological regime showed that reduced rains $\left(153.54 \pm 109.42 \mathrm{~cm}^{3}\right)$ and floodplain influenced the occurrence of these digenean parasites which peaked during dry season months (Nov 2007 - March 2008) when the habitat contracted.
\end{abstract}

Keywords: Clinostomatids, concomitant infection, histopathology, hydrological regime, Tilapia zilii

\section{Introduction}

Recently, the first record of co - infection of three metacercariae of clinostomatids; Clinostomum tilapiae, Clinostomum complanatum, and Euclinostomum heterostomum and description of the parasites of cichlids in Opi lake $\left(6^{0} 45^{\prime} 0 "-45\right.$ $28^{\prime \prime} \mathrm{N}$ and $\left.7^{0} 29^{\prime} 28^{\prime \prime}-7^{0} 29^{\prime} 35^{\prime \prime} \mathrm{E}\right)$ was reported (Echi et. al., 2012). Effects of these digenean parasites on their histopathology have become necessary due to gap in knowledge about such concomitant infections on histopathology and hydrological changes in the occurrence of these parasites. Scarcely, few attempts have been made to describe the histopathology aspect of only a particular Clinostomum sp infection but not co infection on the tissues of infected fish (Adeyemo and Agbede, 2008; Coulibay et. al., 1995; Lo et. al., 1992; Abidi and Nizami, 1987). Therefore, the present attempt was to study its consequences in a co-infection by three different species of Clinostomum sp and the influence of rainfall on the occurrence of these parasites. The changes in occurrence of clinostomatids in response to seasonal variations between the rainy and dry seasons are necessary for better understanding of its Author's Address

${ }^{1}$ Rajiv Gandhi center for Biotechnology, Trivandrum, India

${ }^{2}$ Department of Zoology and Environmental Biology,

University of Nigeria, Nigeria

Email: paul_echi@yahoo.com, echipaulchinedu@gmail.com biology. Parasites induced histopathology is considerably as important as pollution induced (Dey and Kumar, 1986; Loya and Rinkevich 1980; Sakr and Al lail, 2005; Fatma, 2009). Nevertheless, damaged tissues affect the physiology and general health of fish.

Although, 600 years ago have indicated warmer surface temperature than any similar periods (Nicolls et. al., 1995), conventional ongoing changes in hydrological cycles, which has greatly influenced parasitic infections owing to global warming (Patz et. al., 2000), temporal changes in prevalence and abundance of clinostomatids in response to seasonal variations and other abiotic environmental factors in studied aspects of tropical parasite community ecology contain little or information (Juan et. al., 2008). In addition, other larval parasites that infect on direct contact with their hosts share similar gap in knowledge. Conversely, studies on those that are linked by trophic relationships which had conventional occurrences at definite seasons when the reservoir intermediate hosts were readily available and consumed by the fish (Ezenwaji and Ilozumba 1992; Ezenwaji, 2002; Echi, 2005; Juan et. al., 2008; Echi and Ezenwaji, 2010) have been well studied. Eosinophils participate in the inflammatory process of worm infections, allergic reactions, and propagative diseases. Eosinophils are specialized in 
killing and incorporation of large helminth parasites outside the cells through systematic mechanisms of opening cellular granules and its contents. Apart from their proactive activities in inflammatory actions, they also participate in restoration and propagation of tissues that are of epithelial origin. In adaptive immune response they are important effector cells (Hogan, 2007; Anthony et. al., 2007).

\section{Material and methods}

Species of $T$. zillii were caught using multiple fishing gear techniques-cast nets, hook and line, and seine nets $(150 \mathrm{~mm}-200 \mathrm{~mm})$ on monthly basis (Nov 2007 - Oct 2008) as per Olaosebikan and Raji (1998). Duncan's One - way statistical test was used to determine significant difference among body dry weight of the parasites. Rainfall data were obtained from the Metrological unit Department of crop science University of Nigeria, Nsukka. Only freshly caught fish were used for histopathology, affected skin parts was cut- off, fixed in $10 \%$ formalin - saline solution for days prior to paraffin processing: the fixed tissue was transferred through graded series of alcohol - $70 \%, 80 \%, 90 \%$, absolute 1 and 2 solutions for one and half hours in each case to dehydrate the tissues. The alcohol saturated tissue was then transferred to chloroform which cleared the tissue overnight. The chloroform was miscible with both the alcohol and the paraffin wax and also raised the refractive index of the tissue, imparting to it a transparent appearance. Then the tissue was embedded in molten paraffin wax, until the tissue was sufficiently impregnated with the wax, the tissue was embedded in fresh wax which solidified on cooling. The tissue was then sectioned at $5-6$ microns thick, using microtome and stained using hematoxylin eosin stain. The sections were placed on glass slides and viewed under microscope at X 100 and X 400 objective lenses (Echi, 2009; Drury et.al., 1967).

\section{Results and Discussion}

The infection of the three metacercariae of clinostomatids that co-infected T. zillii; Clinostomum complanatum, Euclinostomum heterostomum and Clinostomum tilapiae caused a normal skin of the Cichlids (Plate 1) to degenerate, formation of cysts, skin muscle break down, necrosis and eosinophil cells (Plates 2 and 3), and
Showing the cyst on the skin and partial erosion of the epithelia (Plate 4). The ulcerated skin parts by these parasites could serve as secondary infection route for other parasitic agents such as protozoa, bacteria, fungi and viruses. The infection had highest prevalence among fish size range $10-12$ $\mathrm{cm} 4.85 \%, 2.04 \%$ and $2.04 \%$ in Clinostomum complanatum, Euclinostomum heterostomum and Clinostomum tilapiae respectively.Also, eye damage due to corneal infection resulted in various degrees of eye infection; unilateral exophtalamus, necrotic cells, ulceration of the lining membranes. This will affect the palatability and marketability of the infected fish as well as the acceptance of fish as the primary source of animal protein. It is inferred that these parasites induced mortality (personal observation) due to consequential damages.The occurrence of these metacercariae peaked both in 2007 and 2008 at early dry season (October December 2007) and late dry season (January March 2008) when the rains had subsided with corresponding wide-ranging water level contraction (Fig 1). For instance, the highest prevalence (24\%) of the three Clinostomum parasites was recorded in January 2008, from Clinostomum complanatum recovered from various microhabitat sites out of 158 samples collected. Similarly, C. tilapiae had its highest prevalence (22 \%) in January 2008. Whereas, E. heterostomum collected from different microhabitats of the fish, out of 85 samples recovered had its highest prevalence $(19 \%)$ in November 2007. All occurred in dry season months. Occurrence of both free-living and parasitic species is influenced by limiting conditions of various abiotic factors (Ezenwaji, 2002; Echi, 2005; Echi and Ezenwaji, 2010). Notwithstanding findings of Nicolls et al. (1995) and Patz et al. (2000), the direct infections of clinostomatids larvae maintained its definite infection cycle at early and late dry seasons. Enormous debris of organic matter that influxes the lake collect these infective larvae along with their hosts. Infection probably occurs at clumped portions of increased contact with the hosts. In addition, the lake is in a thick Southern Guinea Savanna area with much surrounding deciduous vegetation. The other months April - August 2008 recorded high rainfall with diminished parasite occurrence levels. The least prevalence was recorded in during the advent of rains, May 2008 


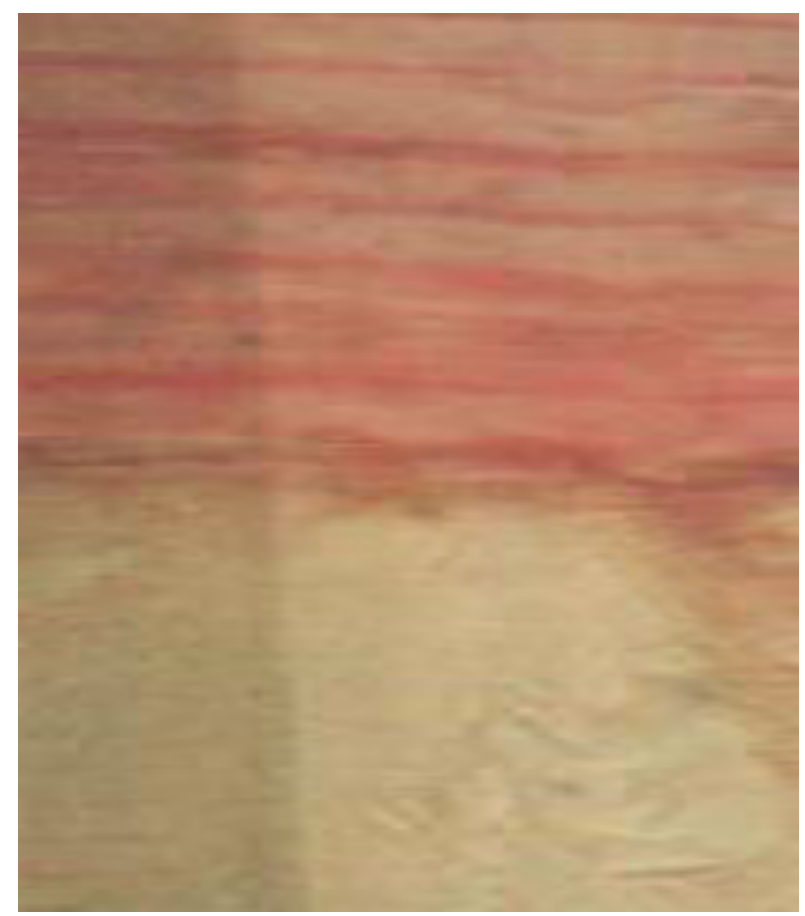

Plate.1: Showing normal skin histological

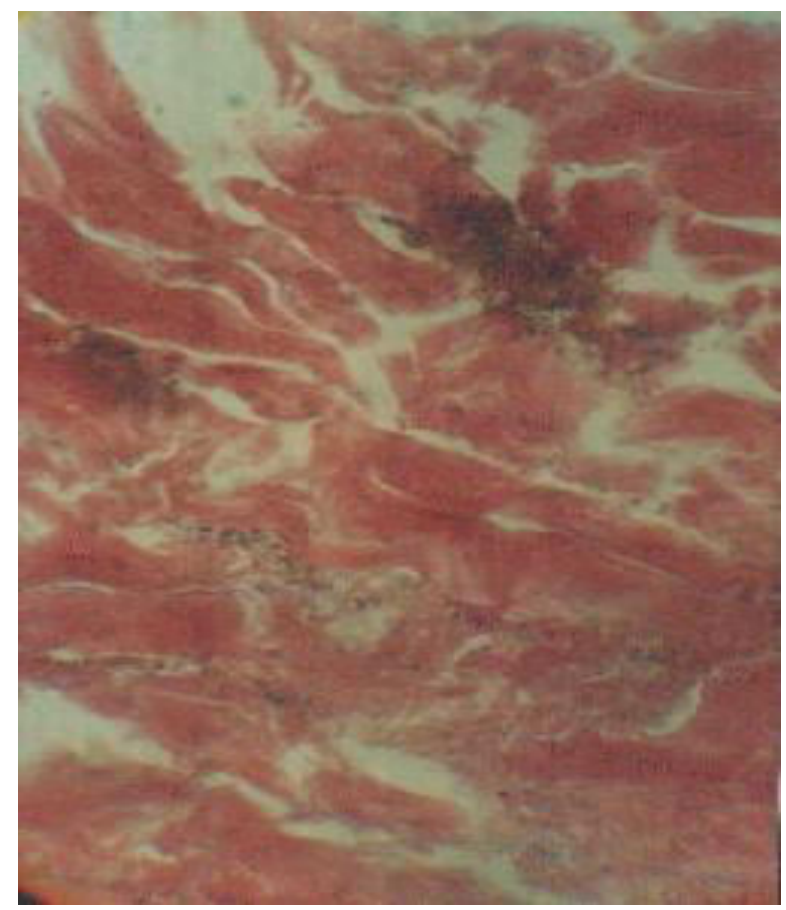

Plate.2: Showing cysts, skin muscle break

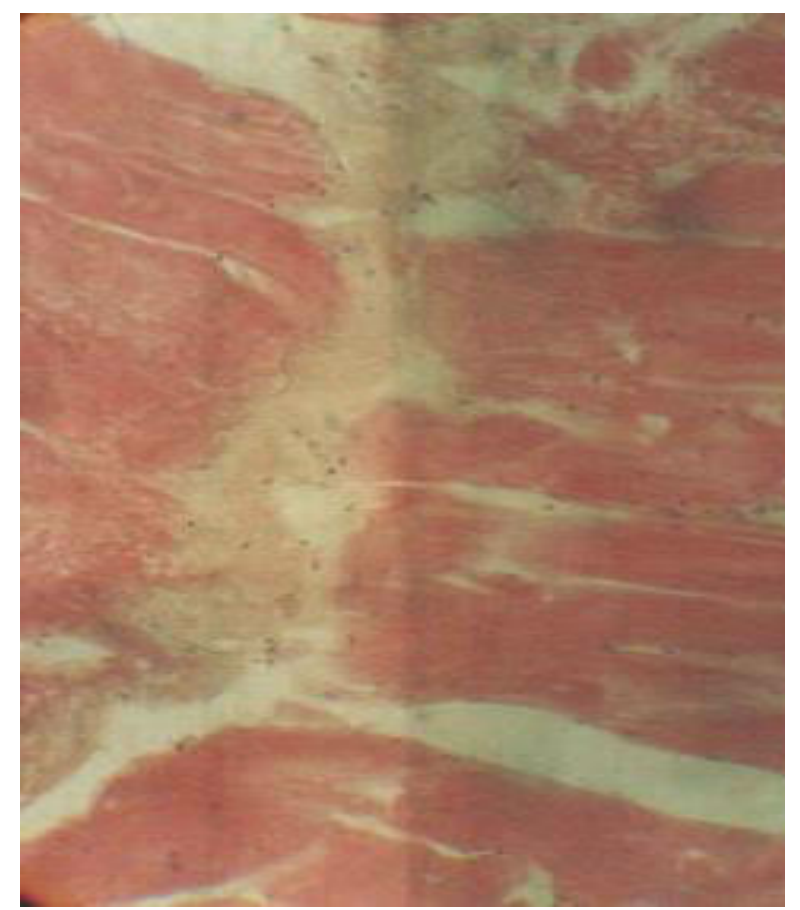

Plate.3: Showing cysts, eosinophils and

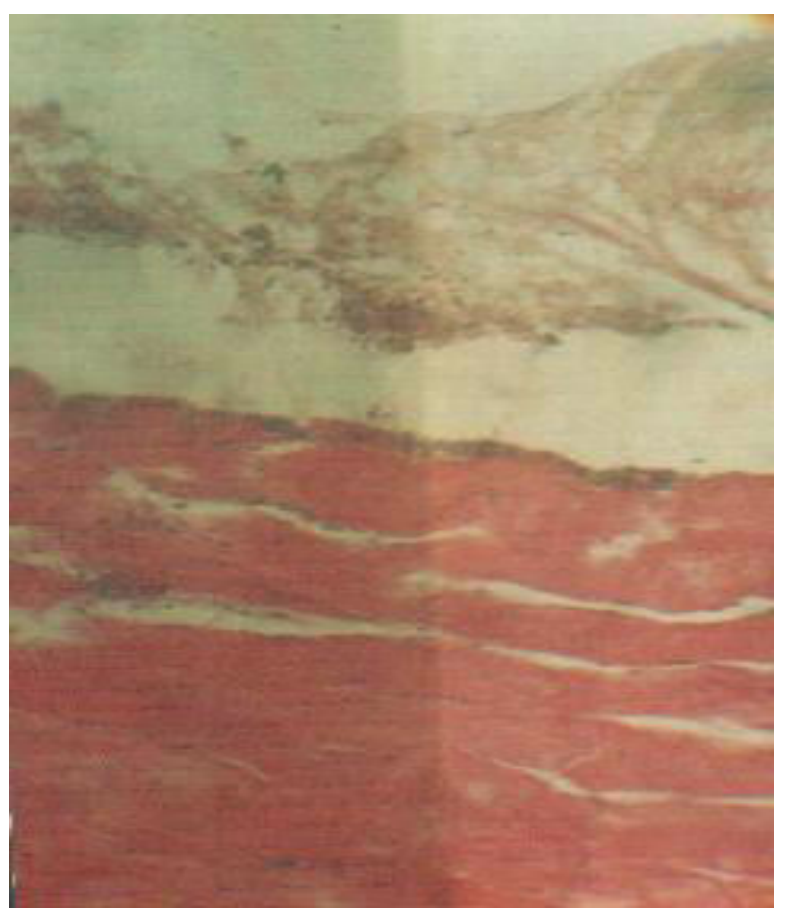

Plate.4: Showing the cyst on the skin and partial erosion of the epithelia 
Table 1: Body Dry Weights (mm) of clinostomatids in Tilapia zillii

\begin{tabular}{|c|c|c|c|}
\hline & $\begin{array}{l}\text { C. complanatum } \\
(\text { Mean } \pm \text { SD) }\end{array}$ & $\begin{array}{l}\text { E. heterostomum } \\
\text { (Mean } \pm \text { SD) }\end{array}$ & $\begin{array}{l}\text { C. tilapiae } \\
(\text { Mean } \pm \mathrm{SD})\end{array}$ \\
\hline Body Weight (mm) & $0.0071 \pm 0.0023^{b}$ & $0.0067 \pm 0.0023^{b}$ & $0.0050 \pm 0.0015^{\mathrm{a}}$ \\
\hline
\end{tabular}

Letters $\mathrm{a}$, and $\mathrm{b}$, show significance difference at $95 \%$ confidence interval $(\mathrm{P}<0.05 \%)$, the figures with similar letters indicate no significance difference, while those with different letters show significance difference.

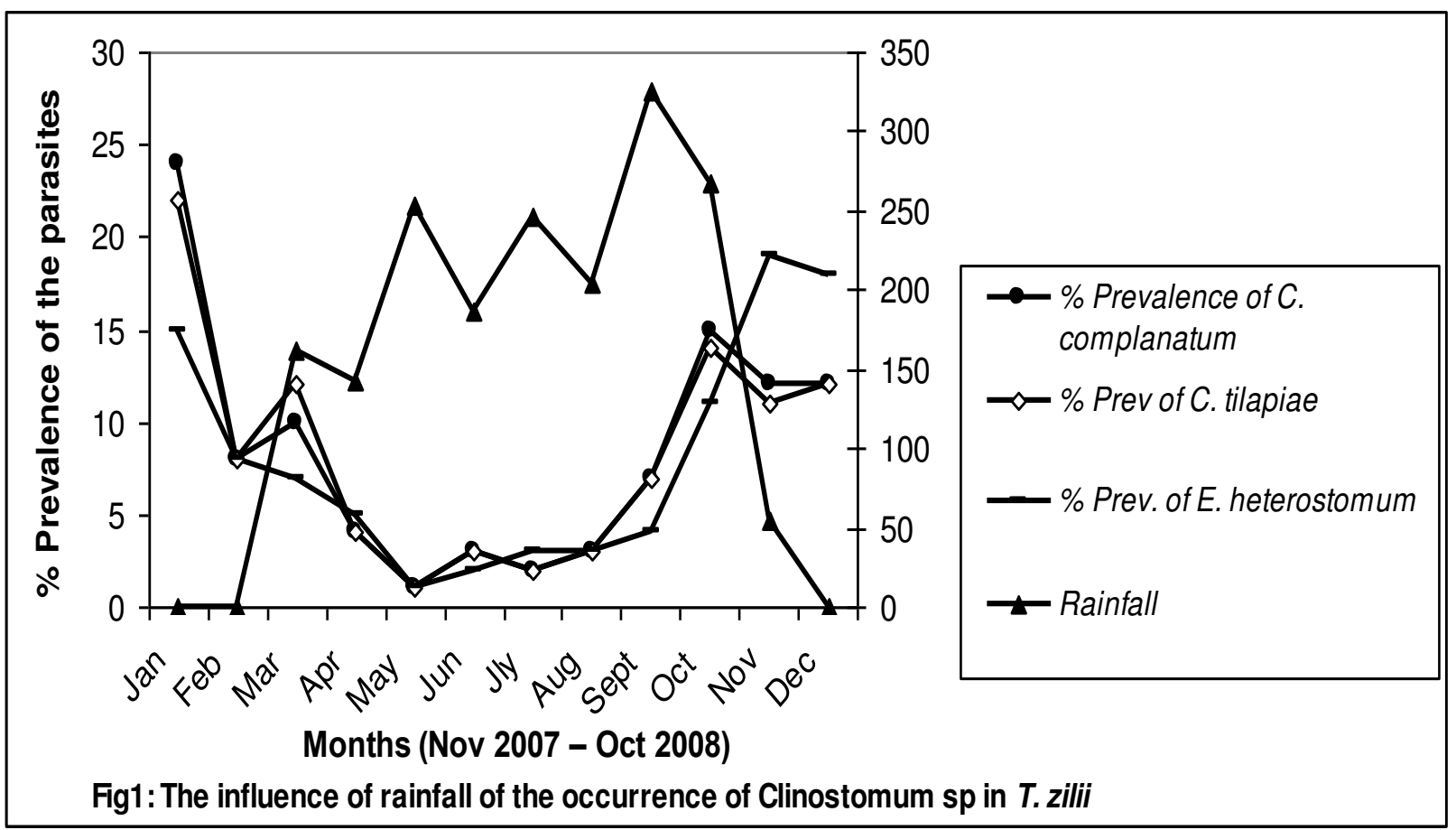

and late rainy season month September, $(1 \%)$ in the three parasites and $(7 \%)$ in Clinostomum complanatum and C. tilapiae respectively, except in E. heterostomum that had $(4 \%)$ during late rainy season of September. Nevertheless, frequent infections occurred during habitat contraction of dry season when chances of contact between the hosts and the larvae will be higher (Juan et al. 2008). Similarly, in places where increased human activities are much around water bank and enormous and indiscriminate influx of refuse could support such infection (Echi, 2005). Due to higher individual numbers and higher dry body weights $C$. complanatum and $E$. heterostomum than $C$. tilapiae, a competitive struggle for survival would can readily remove $C$. tilapiae in the various micro-habitats. Under natural conditions, parasitism may vary seasonally. According to Ezenwaji and Ilozumba (1992) Clarias sp harboured more Euchinostomun clarias, and the larval spiruroid in 
the peak of dry season months (January - March) and early rainy season months (April - June) than in any other months. These were the periods when the cercariae of Euchinostomun clarias, which infected catfish during the late rainy season (July September) and the early dry season (October December), developed to maturity. This is also the period when various intermediate hosts increased in number to facilitate parasitism. Although, Coulibay et al. (1995) there was absence of grave pathology on the infected hosts, the only grave consequence is unacceptability and rejection of fish as a source of food. Ergo, in the present study, as recorded by other authors in a single clinostomatid infection (Adeyemo and Agbede, 2008; Lo et. al., 1992; Abidi and Nizami, 1987), these clinostomatid cysts caused damages due to their presence in the skin and other microhabitats of the fish. These prompted necrotizing responses which were fatal. For the surviving fish these effects will affect the palatability and marketability of the infected fish as well as the acceptance of fish as the primary source of animal protein. It is inferred that these parasites induced mortality perhaps due to consequential damages.Under normal environmental conditions presence of parasites or antigens in the body of animals elicit immune reactions. The effects of these two factors are however, highly suppressive by the vertebrate's body defense mechanism. Eosinophils modulate inflammation by secreting substances that directly reverse the actions of materials secreted by the basophils in the infected skin which was an indication of immunological responses in an attempt to ward - off invading clinostomatids metacercariae (Plates 2 - 4). Also, degenerative changes in the muscle tissues around the cysts, and degeneration of muscle atrophy as well as cellular infiltration in the skin has been recorded from Misgurus anguillicaudatus where metacercariae of Clinostomum complanatum caused muscle atrophy and serious damage to fish tissues and body wall which resulted in fish mortality (Lo et. al., 1992). This can be attributed to fish being the oldest vertebrate animal, show clear similarities with the defense system of mammals and birds which is efficient immune mechanism that is rapid, nonspecific and highly conserved. For instance, in $98 \%$ of multicellular organisms only immunoglobulin is present. The remaining $1.4 \%$ also possesses what is most commonly termed a specific immune response (Watts et. al., 2001).The parasites dry body weight $(\mathrm{mg})$ is being reported for the first, therefore there is no record of such in the past studies. The parasites showed no significant difference in dry body weight $(\mathrm{mg}) ; 0.006 \pm 0.018^{\mathrm{a}}, 0.006 \pm 0.0021^{\mathrm{a}}$, $0.006 \pm 0.0024^{\mathrm{a}},(\mathrm{P}>0.05)$ for Clinostomum complanatum, E. heterostomum, Clinostomum tilapiae respectively. This is suggestive that the parasites are morphologically and phylogenetically related (Table 1).

\section{Acknowledgment}

We thank members of Metrological unit Department of crop science University of Nigeria, Nsukka for providing the rainfall data. Also, thanks go to Messers Clement Ezeora, Ali Sabastine and Ugwu Simon for their field assistance. We declare that there is no conflict of interests.

\section{References}

Abidi, S. M. A and Nizami, W.A. 1987. Developmental changes and histopathology of Clinostomum complanatum (Trematoda) infection in an experimental host. Indi $J$ Parasitol 11:235-238.

Adeyemo, A.O. and Agbede, S.A. 2008. Histopathology of Tilapia tissues harbouring Clinostomum tilapiae parasites. Afr J of Biomed Res 11: 115 - 118

Anthony, R.M., Rutitzky, L.I., Urban, J.F., Stadecker, M.J and Gause, W.C. 2007. Protective immune mechanisms in helminth infection. Nat. Rev. Immunol 7:975-987.

Coulibay, N.D., Salembere, S. and Bessin, R. 1995. Larval Clinostomosis In Cichlid Fish in Lake Kompeinga, Burkina Faso. A threat to Fishing and public Health. Francophones Sante 5:3:199-205

Dey, R. K. and Kumar, D. 1986. Histopathology of microsporidia infection in indian major carp, labeo rohita (hamilton). Paper presented before the International Symposium on Aquaculture and related species held at Paris, during 2-5 September, 1985

Drury, R. A. B. Wallington, E. A. and Cameron, R. 1967. Carleton's Histological Technique. Oxford University press, New York.

Echi, P.C., Eyo, J.E., Okafor, F.C., Onyishi, G.C., Ivoke, N. 2012. First Record of Co - infection of Three Clinostomatid Parasites in Cichlids (Osteichthyes: Cichlidae) in a Tropical Freshwater Lake. Irn J of Pub Hth, 41: 86-90 
Echi et al.

Echi, P.C. and H.M.G. Ezenwaji 2010. The Parasites Fauna of Characids' (Osteichthyes: Characidae) Anambra River, Nigeria. Afr J of Ecol, 48(1): 1- 4.

Echi, P.C. 2009. Ecology, Morphometrics of helminth parasites and histopathological studies of fishes of Opi Lake, Enugu State, Nigeria. Ph.D Thesis University of Nigeria, Nsukka, 162pp.

Echi, P. C. 2005. The parasites of characids (Osteichthyes: Characidae) in Anambra River, Nigeria. M.Sc. Project reports, Department of Zoology, University of Nigeria, and Nsukka.

Ezenwaji, H. M. G. 2002. The biology of Clarias ebriensis Pellegrin, 1920 (Osteichthyes: Clariidae) in an African rainforest river basin. Fis res, 54: 235-252.

Ezenwaji, H. M. G. and Ilozumba, C. O. 1992. Helminth fauna of four West African "small" Clarias $s p$ (Osteichthyes: Clariidae) from Nigeria. J of Afr Zool, 106: 391-400.

Fatma A.S. M. 2009. Histopathological Studies on Tilapia zillii and Solea vulgaris from Lake Qarun, Egypt. Wrld J of Fish and Marine Scis 1: 29-39.

Hogan, S. P. 2007. Recent advances in eosinophil biology. Int Arch Allergy Immunol. 143:3-14.

Juan V. G., Agustín R. H and Ma. L. A. M. 2008. Seasonal patterns in metazoan parasite community of the "Fat Sleeper"Dormitator latifrons (Pisces: Eleotridae) from Tres Palos Lagoon,Guerrero, Mexico. Rev Biol Trop, 56: $1419-1427$
Lo, C. Wang, C. and Kou, G. 1992. The pathology of loach (Misgurnus anguillicandatus) infected with Clinostomum complanatum (Rudolphi, 1814). Act Zool Tiwan, 3:145 154.

Loya, Y. and Rinkevich, B. 1980. Effects of Oil Pollution on Coral Reef Communities. Mar Ecol - Progress Series, 3: 167-180.

Nicolls, N., Gruza, G. V., Karl, T. R., Ogallo, L. A., Parker, D. E. 1995. Observed climate variability and change. In : Houghton, J. T., MeiraFilho L. G., Callander, B. A., Harris, N., Kattenberg, A.,Maskell, K., (eds),The Science of Climate change. Cambridge, Cambridge University Press pp. $133-92$.

Olaosebikan, B. D and Raji, A. 1998. Field guide to Nigerian freshwater fishes. Federal College of Freshwater Fisheries Technology, New Bussa.

Patz, J. A., Englberg, D and Last, J. 2000. The effects of changing wheather on public health. Ann Rev of Pub Hlth, 289: 1763 - 65 .

Sakr S.A. and Al lail S.M. J. 2005. Fenvalerate Induced Histopathological and Histochemical Changes in the Liver of the Catfish Clarias Gariepinus. J of Appl Scis Res, 3: 263-267

Watts, M., Munday, B.L and Burke, C.M. 2001. Immune responses of teleost fish. Aust Vet J, 9: 570 - 574. 